\title{
PROFIL DAYA TAHAN JANTUNG PARU, KEKUATAN OTOT, KELENTUKAN DAN LEMAK MEMBERS BARU FITNESS CENTER CLUB HOUSE CASA GRANDE YOGYAKARTA
}

\section{Oleh: Bagus Dwi Wijaya dan Fatkurahman Arjuna FIK UNY}

\begin{abstract}
Abstrak
Penelitian ini di latar belakangi oleh permasalahan tidak adanya data speksifikasi mengenai pengukuruan awal terhadap members baru yang mencakup tes daya tahan jantung paru, kekuatan otot, kelentukan dan lemak yang bertujuan untuk monitoring perkembangan members baru dari hasil latihan. Penelitian ini dilakukan untuk mengetahui profil daya tahan jantung paru, kekuatan otot, kelentukan dan lemak members baru Fitness Center Club House Casa Grande Yogyakarta.

Penelitian ini merupakan penelitian deskriptif menggunakan metode tes dan pengukuran. Populasi dalam penelitian ini adalah seluruh members baru Center Club House Casa Grande. Sampel dalam penelitian ini adalah members baru pria usia 2024 Fitness Center Club House Casa Grande yang berjumlah 15 orang. Teknik pengambilan sampel dilakukan dengan purposive random sampling. Komponen tes yang diukur yaitu daya tahan jantung paru dengan menggunakan tes lari 12 menit, kelentukan (fleksibilitas) menggunakan sit and reacd test dengan alat fleksometer, kekuatan otot dengan menggunakan pull and push dynamometer, back and leg dynamometer, lemak dengan menggunakan skinfold caliper.

Hasil penelitian yang dilakukan pada members baru Fitness Center Club House Casa Grande Yogyakarta diperoleh hasil: daya tahan jantung paru $40 \%$ dikategorikan kurang, kekuatan otot 73,3 \% dikategorikan sedang, kelentukan 66,7 $\%$ dikategorikan sedang dan lemak 53,3\% dikategorikan sedang.
\end{abstract}

Kata Kunci : Daya Tahan Jantung Paru, Kekuatan Otot, Kelentukan dan Lemak.

Pergeseran pola hidup dari bekerja aktif menjadi jarang bekerja atau pasif merupakan suatu penyebab menurunnya tingkat kebugaran seseorang. Keadaan kurangnya gerak seperti itu menyebabkan berbagai masalah kesehatan, masalah tersebut sangat berbahaya bagi kehidupan manusia. Munculnya berbagai macam penyakit merupakan dampak yang paling nyata dari pola hidup yang tidak sehat. Adapun penyakit yang sering muncul di antaranya jantung koroner, penyakit sendi.

Orang yang sadar akan kehidupannya pasti ingin memiliki tubuh yang sehat dan bugar ingin terhindar dari penyakit serta ingin memiliki tubuh yang ideal dan proporsional, karena tubuh ideal dapat menunjang penampilan seseorang sehingga dapat menimbulkan rasa percaya diri. Olahraga menjadi sebagian aktivitas yang penting di era moderen sebagai penunjang kebugaran dan kesehatan. Menurut Len kravetz (1997: 5) tubuh merupakan mekanisme kompleks yang didesain untuk bergerak. Bugarnya fisik berarti kompleks yang 


\section{MEDIKORA Vol. XII No. 1 April 2014}

didesain untuk bergerak. Bugarnya fisik berarti jantung, pembuluh-pembuluh darah, paruparu dan otot berfungsi dengan baik. Menurut Djoko Pekik Irianto (2004: 4) teerdapat 5 komponen utama dari kebugaran yang berhubungan kesehatan yang harus diperhatikan yaitu (1) daya tahan jantung paru, (2) kekuatan otot, (3) daya tahan otot, (4) kelentukan, dan (5) komposisi tubuh. Dari kelima komponen tersebut komponen yang terpenting adalah daya tahan jantung paru, pembuluh darah, dan grup otot-otot yang besar untuk melakukan latihan-latihan yang keras dalam jangka waktu yang lama.

Menurut Rusli Lutan (1991: 120) paru merupakan salah satu organ tubuh yang mempunyai fungsi penting dalam kehidupan manusia, fungsi paru adalah untuk pertukaran oksigen dengan karbondioksida melalui proses pernapasan. Menurut Len kravetz (1997: 63) tujuan dari pernapasan ialah menyediakan oksigen bagi jaringan dan membuang karbondioksida. Tujuan akhir pernapasan adalah untuk mempertahankan konsentrasi oksigen, karbondioksida, dan ion hidrogen dalam cairan tubuh. Aktifitas pernapasan sangat reponsif terhadap perubahan masing-masing konsentrasi tertentu. Kelebihan karbondioksida atau ion hidrogen akan merangsang pusat pernapasan, dan menyebabkan peningkatan sinyal inspirasi dan ekspirasi yang kuat ke otot pernapasan. Menurut Len kravetz (1997: 68)Oksigen tidak mempunyai efek langsung yang berarti, terhadap pusat pernapasan di otak dalam pengaturan pernapasan. Oksigen bekerja hampir seluruhnya pada komoreseptor perifer yang terletak di aorta, dan badan-badan karotis, kemudian menjalankan sinyal saraf yang sesuai ke pusat pernapasan untuk mengatur pernapasan.

Hal tersebut dapat dicapai dengan adanya program latihan yang dirancang, diprogram dan terencana dengan baik sesuai tujuan latihan akan mendapatkan hasil yang maksimal, sehingga orang merasa puas dengan hasil yang diperoleh. Sekarang ini, semua itu bisa diperoleh dengan mendatangi pusat-pusat kebugaran karena di pusat kebugaran dapat berolahraga tanpa merasa kepanasan ditambah fasilitas yang disediakan cukup banyak dan memadai untuk berolahraga. Setiap pusat kebugaran memiliki fasilitas yang lengkap untuk berolahraga, tempat pusat kebugaran juga harus memiliki program latihan yang betul-betul berkualitas.

Fitness center yang baik seharusnya memberikan tempat yang nyaman dan sertai peralatan fitness yang lengkap sebab, jika fasilitas suatu tempat fitness center kurang memadai akan mempengaruhi kualitas tempat fitness center tersebut, seperti halnya Fitness Center Club House Casa Grande. Suatu tempat fitness center umumnya mempunyai data profil kebugaran untuk members baru, agar members tersebut mengetahui kondisi 


\section{MEDIKORA Vol. XII No. 1 April 2014}

kebugarannya, sehingga instruktur dapat mengarahkan program latihan yang lebih baik kepada members tersebut. Dalam hal ini di Fitness Center Club House Casa Grande tidak memiliki data spesifikasi tentang profil kebugaran members baru, sehingga members baru tersebut belum mengetahui kondisi kebugarannya.

Manfaat data profil daya tahan jantung paru, kekuatan otot, kelentukan dan lemak adalah, (1) untuk mengetahui kondisi kebugaran members, (2) untuk menentukan program latihan yang tepat dan pemantauan perkembangan yang dilakukan members saat latihan. Members yang termasuk dalam penelitan ini adalah members baru yang sudah berlatih di Fitness Center Club House Casa Grande kurang lebih selama 1 bulan. Untuk menjawab permasalahan yang timbul dalam latar belakang ini yaitu tidak adanya penanganan yang baik dari Fitness Center Club House Casa Grande dan instruktur terhadap members baru dalam pemberian program latihan, monitoring program, bahkan sampai ke pengenalan alat. Dengan demikian akan timbul merosotnya tingkat daya tahan jantung paru, kekuatan otot, kelentukan dan lemak, sehingga peneliti tertarik untuk menguji sejauh mana tingkat daya tahan jantung paru, kekuatan otot, kelentukan dan lemak yang ada pada members baru di Fitness Center Club House Casa Grande. Dibutuhkan data empirik mengenai profil daya tahan jantung paru, kekuatan otot, kelentukan dan lemak members baru Fitness Center Club House Casa Grande. Berdasarkan pentingnya data profil tersebut, maka penulis tertarik untuk mengadakan penelitian yang berjudul profil daya tahan jantung paru, kekuatan otot, kelentukan dan lemak members baru Fitness Center Club House Casa Grande Yogyakarta.

\section{Pengertian Profil}

Profil merupakan salah satu komponen penting pada individu. Profil dapat diartikan sebagai rupa, penampilan yang kelihatan, lebih cenderung dilihat dari segi fisik yang terlihat, demikian menurut Wahjoedi (2001: 59-60) fisik meliputi, seluruh komponen yang ada pada individu bisa dilihat dari prilaku keseharian individu tersebut. Seseorang bertubuh tinggi, berperawakan kurus, dengan karakter orang rajin dan pendiam, dilihat dari segi fisiknya profil orang tersebut dikatakan bertubuh tinggi kurus dengan karakter pendiam.

Profil dipengaruhi oleh gaya hidup seseorang atau aktivitas yang dilakukan sehari-hari. Beberapa hal yang mempengaruhi suatu profil seseorang antara lain makanan yang dikonsumsi dan aktivitas sehari-hari. Keadaan tersebut terjadi karena tubuh seseorang akan beradaptasi dengan keadaan lingkungan. Seseorang mengkonsumsi makanan yang berlebihan dan kurang melakukan aktivitas fisik maka tubuh akan beradaptasi dengan menyimpan timbunan lemak berlebih, dan mengakibatkan obesitas atau kegemukan, dengan 


\section{MEDIKORA Vol. XII No. 1 April 2014}

rutin melakukan olahraga atau aktivitas fisik, maka tubuh akan beradaptasi dengan membentuk otot tubuh. Bentuk tubuh proporsional dan sehat dipengaruhi oleh gaya hidup seseorang.

\section{Pengertian Daya Tahan Jantung}

Menurut Djoko Pekik Irianto (2004: 4) menyatakan, "daya tahan jantung-paru adalah kemampuan jantung-paru mensuplai oksigen untuk kerja otot jangka waktu yang lama." Seseorang yang memiliki daya tahan jantung-paru baik, tidak akan cepat kelelahan setelah melakukan serangkaian kerja. Misalanya, pada saat naik tangga dari lantai dasar hingga lantai 3 tidak akan terengah-engah secara berlebihan. Berikut ini akan dijelaskan beberapa komponen yang berhubungan dengan daya tahan jantung-paru sebagai berikut,

\section{A. Pengertian $V O^{2}$ Max}

$V O^{2} \mathrm{Max}$ adalah kemampuan organ pernafasan manusia untuk menghirup oksigen sebanyak-banyak pada saat latihan (aktivitas jasmani), (Sukadiyanto 2011: 83). Secara praktis kebugaran paru-jantung dapat diprediksi dengan mengukur detak jantung istirahat, yaitu detak jantung yang dihitung pada bangun tidur pagi hari sebelum turun dari ranjang, tidak sedang dalam keadaan sakit, tidak stress fisik maupun psikis dan sebaiknya dikerjakan selama 3 hari berturut-turut untuk mendapatkan angka rata-rata.

B. Ciri-ciri latihan daya tahan jantung paru

Menurut Djoko Pekik Irianto (2004: 29) menyebutkan, 3 ciri-ciri latihan daya tahan jantung-paru meliputi:

1) Gerak yang melibatkan otot-otot besar, secara anatomis otot-otot besar tubuh terletak pada bagian tubuh bawah atau tungkai sehingga model latihan berjalan atau berlari lebih baik dibandingkan gerakan mendayung, 2) Tipe gerak kontinuritmis ini, adalah gerakan yang dilakukan dalam jangka waktu tertentu secara terus-menerus tanpa berhenti dengan irama gerak ajeg. Misalnya, bersepeda atau joging dengan kecepatan tertentu. Olahraga permainan (bola voli, teknis, bulutangkis) kurang dianjurkan karena pada olahraga permainan banyak gerakan yang dilakukan terputus-putus, kadang cepat kadang lambat, atau berhenti sama sekali, 3) Sifat gerak aerobik ini, merupakan gerakan yang dilakukan pada intensitas sedang yang diukur dengan kenaikan detak jantung latihan, misalnya: lari dengan kecepatan sedang, bukan lari cepat.

C. Takaran latihan daya tahan jantung paru

Latihan dibutuhkan untuk meningkatkan kapasitas dan daya tahan jantung-paru dan dilakukan secara progresif sesuai dengan kebutuhan latihannya, mengacu pada Djoko Pekik Irianto (2004: 29) bahwa, ada 3 takaran latihan daya tahan jantung-paru meliputi:

1. Frekuensi, untuk mendapatkan kebugaran jantung-paru latihan dilakukan secara teratur 


\section{MEDIKORA Vol. XII No. 1 April 2014}

\section{3-5 kali/minggu.}

2. Intensitas, $75-85 \%$ detak jantuk maksimal. Bagi mereka yang baru mulai latihan atau usia lanjut mulailah berlatih pada intensitas lebih rendah misalnya $60 \%$ terus tingkatkan secara bertahap hingga mencapai intensitas latihan yang semestinya.

3. Time (Durasi), setiap berlatih kerjakan selama 60 menit tanpa berhenti.

\section{Pengertian Kekuatan dan Daya Tahan Otot}

Menurut Sukadiyanto (2011: 91) mengemukakan bahwa, "pengertian kekuatan secara umum adalah kemampuan otot atau sekelompok otot untuk mengatasi beban atau tahanan." Pengertian secara fisiologi, kekuatan adalah kemampuan neuromuskuler atau tahanan beban luar dan beban dalam.

Tingkat kekuatan diantaranya dipengaruhi oleh keadaan, panjang pendeknya otot, besar kecilnya otot, jauh dekatnya titik tumpu, tingkat kelelahan, jenis otot merah atau putih, potensi otot, pemanfaatan potensi otot, teknik, dan kemampuan kontraksi otot, (Sukadiyanto 2011: 91).

A. Macam-macam kontraksi otot

Menurut Wahjoedi (2001: 60) menyatakan, ada 3 macam kontraksi otot yang meliputi:

1) Kontraksi Isometrik adalah suatu kontraksi yang tidak ditandai oleh pemendekan atau pemanjangan otot di mana tegangan otot meningkat selama kontraksi dan beban tidak berpindah, 2) Kontraksi Isokinetik adalah suatu kontraksi yang menyebabkan terjadinya pemendekan otot dengan kecepatan yang tepat dan menempuh ruang gerak sendi secara penuh, 3) Kontraksi Eksentrik adalah suatu kontraksi yang ditandai adanya pemanjangan otot di mana gerakan terjadi searah dengan gaya beban berupa gerakan mengambilkan beban ke tempatnya.

B. Ciri-ciri latihan kekuatan dan daya tahan otot

Ciri utama latihan untuk meningkatkan kekuatan dan daya tahan otot adalah latihan dengan gerak melawan beban, baik beban berat badan sendiri atau beban luar (dambel, barbell, bola, medicine, mesin beban, dan lain-lain). Menurut Djoko Pekik Irianto (2004: 35) menyatakan, "Untuk kekuatan otot gunakan beban berat dengan ulangan sedikit, daya tahan otot memerlukan beban ringan dengan ulangan banyak, sedangkan beban menengah akan memperbesar ukuran otot (hipertropi) seperti, pembentukan tubuh (body builder) atau menambah berat badan." 


\section{MEDIKORA Vol. XII No. 1 April 2014}

\section{METODOLOI PENELITIAN}

Penelitian ini adalah penelitian deskriptif, artinya dalam penelitian ini hanya ingin menggambarkan situasi yang saat ini sedang berlangsung, tanpa pengujian hipotesis (Suharsimi Arikunto, 2003: 301). Metode yang digunakan dalam penelitian ini menggunakan metode tes dan pengukuran.

Populasi dalam penelitian ini adalah seluruh members baru di Fitness Center Club House Casa Grande. Pengambilan sampel dalam penelitian ini menggunakan teknik purposive random sampling. Menurut Suharsimi Arikunto (2003: 128) purposive random sampling ialah pengambilan sampel yang bertujuan dengan menentukan kriteria yang meliputi: (1) members laki-laki yang berusia 20-24 tahun. (2) members yang baru bergabung dalam rentan waktu 1 bulan sampai 2 bulan. (3) members yang bersedia untuk melakukan tes daya tahan jantung paru, tes kekuatan otot, tes kelentukan dan tes lemak tubuh yang diberikan oleh peneliti. Melalui kriteria tersebut maka diperoleh sampel dalam penelitian ini yang berjumlah 15 orang.

\section{HASIL PENELITIAN}

\section{Daya Tahan Jantung Paru}

Tes daya tahan jantung paru diukur mengunakan tes lari 12 menit. Daya tahan jantung paru members baru Fitness Center Club House Casa Grande Yogyakarta berada pada kategori baik sekali sebesar $0 \%$, kategori baik sebesar 6,7\%, kategori sedang sebesar 20 $\%$, kategori kurang sebesar $40 \%$, dan kategori kurang sekali sebesar 33,3\%. Dijabarkan pada tabel sebagai berikut

Tabel 1. Deskripsi Hasil Tes Daya Tahan Jantung Paru

\begin{tabular}{|c|c|c|c|}
\hline Interval & Kategori & Frekuensi & Persentase (\%) \\
\hline $20-29$ & & & 0 \\
\hline$>2.65$ & Baik Sekali & 0 & 6,7 \\
\hline $2.41-2.64$ & Baik & 1 & 20,0 \\
\hline $2.12-2.40$ & Sedang & 3 & 40,0 \\
\hline $1.96-2.10$ & Kurang & 6 & 33,3 \\
\hline$<1.96$ & Kurang Sekali & 5 & 100 \\
\hline
\end{tabular}

\section{Kekuatan Otot}

Penelitian ini menggunakan 4 tes pengukuran kekuatan otot yaitu pull and push dynamometer, leg and back dynamometer. Hasil tes kekuatan diuraikan sebagai berikut: 


\section{A. Pull Dynamometer}

Hasil penelitian tes pull dynamometer members baru Fitness Center Club House Casa Grande Yogyakarta dari 15 members berada pada kategori baik sekali sebesar 6,7 $\%$, kategori baik sebesar 53,3\%, kategori sedang sebesar 26,7 \%, kategori kurang sebesar $13 \%$, dan kategori kurang sekali sebesar $0 \%$. Deskripsi hasil tes lemak dapat dilihat pada tabel di bawah ini:

Tabel 2. Deskripsi Hasil Tes Pull Dynamometer

\begin{tabular}{|c|c|c|c|}
\hline Interval & Kategori & Frekuensi & Persentase (\%) \\
\hline$>44$ & Baik Sekali & 1 & 6,7 \\
\hline $34-43$ & Baik & 8 & 53,3 \\
\hline $25-33$ & Sedang & 4 & 26,7 \\
\hline $18-24$ & Kurang & 2 & 13,3 \\
\hline$<17$ & Kurang Sekali & 0 & 0 \\
\hline \multicolumn{2}{|c|}{ Jumlah } & $\mathbf{1 5}$ & $\mathbf{1 0 0}$ \\
\hline
\end{tabular}

B. Push Dynamometer

Hasil penelitian push dynamometer members baru Fitness Center Club House Casa Grande Yogyakarta dari 15 members berada pada kategori baik sekali sebesar 6,7 $\%$, kategori baik sebesar 33,3\%, kategori sedang sebesar $60 \%$, kategori kurang sebesar $0 \%$, dan kategori kurang sekali sebesar $0 \%$. Deskripsi hasil tes lemak dapat dilihat pada tabel di bawah ini

Tabel 3. Deskripsi Hasil Tes Push Dynamometer

\begin{tabular}{|c|c|c|c|}
\hline Interval & Kategori & Frekuensi & Persentase (\%) \\
\hline$>44$ & Baik Sekali & 1 & 6,7 \\
\hline $34-43$ & Baik & 5 & 33,3 \\
\hline $25-33$ & Sedang & 9 & 60 \\
\hline $18-24$ & Kurang & 0 & 0 \\
\hline$<17$ & Kurang Sekali & 0 & 0 \\
\hline & Jumlah & $\mathbf{1 5}$ & $\mathbf{1 0 0}$ \\
\hline
\end{tabular}

\section{Kelentukan (Flekksibilitas)}

Kelentukan dalam penelitian ini diukur dengan menggunakan alat fleksometer, hasil penelitian kelentukan members baru pria Fitness Center Club House Casa Grande Yogyakarta dari 15 members, berada pada kategori baik sekali sebesar $0 \%$, kategori baik sebesar $20 \%$, kategori sedang sebesar $66,7 \%$, kategori kurang sebesar $2 \%$, dan kategori 
kurang sekali sebesar $0 \%$. Deskripsi hasil tes kelentukan (fleksibilitas) dapat dilihat pada tabel di bawah ini:

Tabel 4. Deskripsi Hasil Tes Kelentukan (Fleksibilitas)

\begin{tabular}{|c|c|c|c|}
\hline Interval & Kategori & Frekuensi & $\begin{array}{c}\text { Persentase } \\
(\mathbf{\%})\end{array}$ \\
\hline$>5$ & Baik Sekali & 0 & 0 \\
\hline $40-$ & Baik & 3 & 20 \\
\hline $29-$ & Sedang & 10 & 66,7 \\
\hline $23-$ & Kurang & 2 & 13,3 \\
\hline$<2$ & Kurang Sekali & 0 & 0 \\
\hline & Jumlah & $\mathbf{1 5}$ & $\mathbf{1 0 0}$ \\
\hline
\end{tabular}

\section{Lemak}

Hasil penelitian members baru Fitness Center Club House Casa Grande Yogyakarta members baru pria Fitness Center Club House Casa Grande Yogyakarta dari 15 members, berada pada kategori baik sekali sebesar $0 \%$, kategori baik sebesar $20 \%$, kategori sedang sebesar $66,7 \%$, kategori kurang sebesar $2 \%$, dan kategori kurang sekali sebesar $0 \%$. Deskripsi hasil tes kelentukan dapat dilihat pada tabel sebagai berikut.

Tabel 5. Deskripsi Hasil Tes Lemak

\begin{tabular}{|l|c|c|c|}
\cline { 1 - 2 } \multicolumn{1}{|c|}{ Interval } & \multirow{2}{*}{ Kategori } & Frekuensi & Persentase (\%) \\
\cline { 1 - 3 } $\mathbf{1 8 - 3 4}$ & & 0 & 0 \\
\hline $10.0-10.8$ & Baik Sekali & 7 & 46.7 \\
\hline $11.7-15.0$ & Baik & 8 & 532 \\
\hline $25.1-23.8$ & Sedang & 0 & 0 \\
\hline & Kurang & $\mathbf{1 5}$ & 100 \\
\hline
\end{tabular}

\section{PEMBAHASAN}

Dalam penelitian ini profil members baru pria usia 20-24 di Fitness Center Club House Casa Grande di ukur dengan 4 komponen yaitu daya tahan jantung paru, kekuatan otot, kelentukan dan lemak. Berdasarkan deskripsi hasil penelitian di atas dapat diuraikan sebagai berikut:

A. Daya Tahan Jantung Paru

Berdasarkan hasil penelitian di atas di peroleh daya tahan jantung paru members baru Fitness Center Club House Casa Grande sebagian besar masuk dalam kategori kurang 40 $\%$, hal tesebut diartikan kebugaran members pria di ukur dari tes daya tahan jantung 


\section{MEDIKORA Vol. XII No. 1 April 2014}

paru masih kurang. Members yang masuk dalam kategori kurang dan kurang sekali disebabkan latihan yang kurang intensif dan tidak teratur. Sehingga kebugarannya masih kurang dari cukup, karena menurut Djoko Pekik Irianto (2004: 29) bahwa, ada 3 takaran latihan daya tahan jantung-paru meliputi: (a) Frekuensi, untuk mendapatkan kebugaran jantung-paru latihan dilakukan secara teratur 3-5 kali/minggu. (b) intensitas, 75-85\% detak jantuk maksimal. Bagi mereka yang baru mulai latihan atau usia lanjut mulailah berlatih pada intensitas lebih rendah misalnya $60 \%$ terus tingkatkan secara bertahap hingga mencapai intensitas latihan yang semestinya. (c) Time (Durasi), setiap berlatih kerjakan selama 60 menit tanpa berhenti. Sedangkan members yang masuk dalam kategori sedang, baik dan baik sekali dikarenakan frekuensi, intensitas dan waktu latihan yang rutin dan teratur sehingga daya tahan jantung paru members stabil dan baik.

B. Kekuatan Otot

Dalam penelitian ini, pengukuran kekuatan otot dari empat alat tes kekuatan otot. hasil penelitian diperoleh kekuatan otot members baru pria usia 20-24 di Fitness Center Club House CasaGrande sebagian besar masuk dalam kategori sedang.

Berdasarkan hasil penelitian members baru Fitness Center Club House Casa Grande yang masuk dalam kategori sedang 73,3\%, diartikan mempunyai kekuatan otot yang cukup baik. Hal tersebut dikarenakan members dalam latihan mempunyai intensitas latihan yang hampir rutin dan teratur. Sedangkan yang masuk dalam kategori baik, diartikan mempunyai kekuatan otot yang baik dan mempunyai intensitas latihan yang rutin dan teratur, dikarenakan members melakukan latihan yang intensif sehingga kekuatan otot sudah beradaptasi dan meningkat.

Kekuatan tiap individu seseorang memang berbeda-beda tergantung dari kondisi fisik tiap individu, akan tetapi kondisi fisik tersebut dapat dilatih. Seseorang yang sering berolahraga tubuhnya telah beradaptasi, sehingga kekuatan yang dimiliki menjadi lebih besar dan lebih baik dibanding dengan orang yang hanya melakukan kegiatan sehari-hari saja.

C. Kelentukan

Berdasarkan hasil penelitian di atas diperoleh profil members baru Fitness Center Club House Casa Grande berdasarkan tes kelentukan sebagian besar masuk dalam kategori sedang 66,7 \%, hal tersebut intensitas latihan beban pada members pria di Fitness Center Club House Casa Grande yang cukup baik, dikarenakan mempunyai intensitas latihan yang hampir rutin dan teratur. Orang yang melakukan olahraga lebih 


\section{MEDIKORA Vol. XII No. 1 April 2014}

rutin dan teratur fleksibilitas tubuhnya lebih baik. Dikarenakan latihan yang dilakukan, pastilah akan melibatkan otot-otot tubuh untuk bergerak, sehingga kelentukan akan tetap terjaga dan tetap lentuk.

D. Lemak

Kadar lemak seseorang dapat diatur dengan latihan atau olahraga yang teratur setiap hari. Pada penelitian ini alat yang digunakan untuk mengukur lemak adalah skinfold caliper. Dengan cara mencubit 4 bagian tubuh yaitu biceps, triceps, subscapular, suprailliaca.

Berdasarkan hasil penelitian di atas pengukuran lemak pada members baru Fitness Center Club House Casa Grande sebagian besar pada kategori sedang 53,3 \%, members yang masuk dalam kategori sedang diartikan cukup. Hal tersebut dikarenakan members di Fitness Center Club House Casa Grande mempunyai kadar lemak yang sudah cukup atau normal. Kadar lemak sangat penting untuk menjaga penampilan, karena orang yang mempunyai kadar lemak kurang akan terlihat kurus dan orang yang mempunyai kadar lemak berlebihan akan terlihat gemuk.

\section{KESIMPULAN}

Dari hasil penelitian yang dilakukan pada 15 orang members baru Fitness Center Club House Casa Grande Yogyakarta di peroleh hasil: daya tahan jantung paru $40 \%$ dikategorikan kurang, kekuatan otot 73,3 \% dikategorikan sedang, kelentukan 66,7 \% dikategorikan sedang, lemak 53,3\% dikategorikan sedang.

\section{DAFTAR PUSTAKA}

Djoko Pekik Irianto. (2004). Pedoman Praktis Berolahraga untuk Kebugaran dan Kesehatan. Yogyakarta: Andi.

Krevitz, Len. (2001) Panduan Lengkap Bugar Total. Jakarta: PT Raja Grafindo Persada.

Rusli Lutan. (1991). Manusia dan Olahraga. Bandung: ITB dan FPQK atau IKIP.

Suharsimi Arikunto. (2003). Manejeman Penelitian. Jakarta: Rineka Cipta. . (2010). Prosedur Penelitian Suatu Pendekatan Praktik. Jakarta: Rineka Cipta.

Sukadiyanto. (2002). Teori dan Metodologi Melatih Fisik Petenis. Yogyakarta: Universitas Negeri Yogyakarta. 
MEDIKORA Vol. XII No. 1 April 2014

Wahjoedi. (2001). Landasan Evaluasi Pendidikan Jasmani. Jakarta: Depdiknas. 